\title{
Using spatial genetic structure of a population of Swietenia macrophylla King to integrate genetic diversity into management strategies in Southwestern
}

\section{Amazon}

\author{
Sabrina Silva de Oliveira ${ }^{\mathrm{a}}$, Tatiana Campos ${ }^{\mathrm{b}, *}$, Alexandre Magno Sebbenn $^{\mathrm{c}}$, \\ Marcus Vinicio Neves d'Oliveira ${ }^{\mathrm{b}}$ \\ ${ }^{\text {a }}$ Graduate Program in Forest Science, Federal University of Acre, Rio Branco, Acre, Brazil \\ ${ }^{\mathrm{b}}$ Embrapa Acre, Rio Branco, Acre, Brazil \\ ${ }^{\mathrm{c}}$ Forest Institute of São Paulo, CP 1322, São Paulo, SP 01059-970, Brazil
}

\section{A R T I C L E I N F O}

\section{Keywords:}

Conservation genetics

Forest logging

Mahogany

Microsatellite loci

Spatial genetic structure

Tropical tree

\begin{abstract}
A B S T R A C T
The aims of this study were to investigate the intrapopulation spatial genetic structure (SGS) of a preserved Swietenia macrophylla population in a managed forest in Southwestern Amazon, in Acre state, Brazil, and assess the genetic parameters that underlie the conceptual framework that guides conservation and management strategies. The study was conducted in Annual Production Unit (APU) 3, where 83 adult trees (DBH $\geq 40 \mathrm{~cm}$ ) were mapped (1650 ha). The diameter at breast height (DBH) was measured and the vascular exchange was sampled. Leaf tissues were collected from 187 juvenile individuals within a radius of $20 \mathrm{~m}$ of adults. The population presented high heterozygosity $\left(\mathrm{H}_{\mathrm{o}}\right)$ for adult $(0.767)$ and juvenile $(0.763)$ individuals, but significantly high allelic richness $(R)$ and significantly lower fixation index $(F)$ in adults $(R=10.3, F=0.048)$ than juveniles $(R=9.3, F=0.119)$. The $F$ value significantly higher for juveniles, suggesting selection against inbred individuals between juvenile and adult life stages. SGS was detected for adults up to $300 \mathrm{~m}$. Mating was mainly through outcrossing (0.97-1.0), but some crossing occurred among related trees (0.02-0.16) and were correlated $\left(r_{\mathrm{pm}}=0.06-0.22\right)$, indicating a mean effective number of pollen donors ranging from 4.5 to 18.2. Pollen dispersal distances reached $3905 \mathrm{~m}$ (mean of $1472 \mathrm{~m}$ ), and mean effective pollination neighbor area of $792 \mathrm{ha}$. The effective population size $\left(\mathrm{N}_{\mathrm{e}}\right)$ within family (2.73) was lower than expected for random mating populations. The number of trees $(\mathrm{m})$ required for seed collection was estimated at 55 non-inbreed and not related trees to each other. The core collection consisted of 42 (50.6\%) adults across the area. These individuals should be included in seed collection as they represent $100 \%$ of the total detected genetic diversity. The inclusion of $S$. macrophylla on the list of species available for exploitation is not indicated, because the species requires cross breeding for its maintenance and logging reduce the $\mathrm{N}_{\mathrm{e}}$ and may negatively impact the pattern of genetic diversity. These will significantly increase the risk of genetic erosion and population extinction due to a lack of adaptive ability. Adults serve as pollen donors that ecologically and genetically contribute to the maintenance of gene flow and $\mathrm{N}_{\mathrm{e}}$. Because it is recognized as a threatened species worldwide, and due to the fact that in areas of natural occurrence the species presents low-density and shows difficulty establishing natural regeneration, we recommend that $S$. macrophylla be protected from selective logging.
\end{abstract}

\section{Introduction}

The Neotropical tree Swietenia macrophylla King (mahogany) occurs throughout the tropical region of the Americas, including southeastern Mexico, along the Atlantic coast of Central America, and northern South America (Moghadamtousi et al., 2013). Due to the excellent aesthetic, physical and mechanical characteristics of its wood (Neto et al., 2004; André et al., 2008), it has high commercial value with prices ranging from US\$ 200 to 800 per cubic meter (SEFA, 2015). The species has been exploited extensively, particularly during the 1970 s and '80s, which brought about a sharp decline in its populations in areas of natural occurrence (André et al., 2008; Sebbenn et al., 2012; Degen et al., 2013; Alcalá et al., 2014). As such, S. macrophylla has been included on the list of endangered species (CITES, 2019), which

\footnotetext{
* Corresponding author.

E-mail address: tatiana.campos@embrapa.br (T. Campos).
} 
advocates for the controlled trade of the species to avoid use that is incompatible with its survival. It is also listed on Brazil's official endangered flora species list (Brazil, 2015). Thus, it is essential to conduct genetic and ecological studies to support conservation planning.

Following several efforts to suspend the exploitation of the species in Brazil, Normative Instruction No. 1 allows for the approval of Sustainable Forest Management Plans (SFMP) and their related Annual Operational Plans (AOP), when considering the exploitation of vulnerable species in the Amazon biome (Brazil, 2015). For S. macrophylla, Brazilian legislation permits the harvesting of $80 \%$ of trees with a diameter at breast height (DBH) $\geq 60 \mathrm{~cm}$, with a minimum conservation of $20 \%$ of trees as seed carriers (SEMAS, 2015). Although the current forest management model incorporates the concept of reduced impact logging (RIL), it has been criticized for promoting the reproductive isolation of species and favoring non-random mating, which may contribute to increases in inbreeding and lead to genetic erosion. This is particularly this case for species such as $S$. macrophylla that generally present a low density $(<1$ tree/ha) in natural populations (André et al., 2008; Sebbenn et al., 2008; Lacerda et al., 2013; TrujilloSierra et al., 2013; Alcalá et al., 2015). Genetic studies have reported that S. macrophylla has high levels of genetic diversity and differentiation among populations in areas without logging (Lemes et al., 2003; Degen et al., 2013). Although the species may be self-incompatible (Bawa et al., 1985), studies based on genetic markers as microsatellite loci have reported a loss of genetic diversity and increased inbreeding as a result of forest fragmentation and logging of its natural habitat (André et al., 2008; Sebbenn et al., 2012; Breed et al., 2012; Degen et al., 2013; Trujillo-Sierra et al., 2013). The juveniles assigned with estimates of genetic diversity and structure, inbreeding, pollen dispersal, and mating patterns can be used as additional measures to inform sustainable forest management practices and help to understand the impacts of forest management on the spatial genetic structure (SGS) of managed species (Gillies et al., 1999; Lourmas et al., 2007; Sebbenn et al., 2012; Baldauf et al., 2013; Degen et al., 2013; Lacerda et al., 2013; Vinson et al., 2015, 2018; Arruda et al., 2015; Dal Bem et al., 2015; Duminil et al., 2016). Forest logging decrease the population size, increasing the distance among reproductive trees and vegetation density, affecting the behavior of pollen and seed disperse vectors, and recruitment, changing the spatial genetic structure (SGS) of logged populations (Silva et al., 2008; Lacerda et al., 2008; Carneiro et al., 2009, 2011; Vinson et al., 2015; Arruda et al., 2015). As Swietenia macrophylla present generally low population density, pollination occurs by small insects (trips), the seeds are dispersed by the wind, but due to their weight, they usually fall close to the mother tree (Gullison et al., 1996), the SGS can be altered, due to the possibility of increasing the rate of self-fertilization, correlated matings between the remaining trees after logging, increasing the proportion of full-sibs in the seeds produced by a tree. Furthermore, due to the opening of clearings by logging, as the species and heliophyte, its can favor the regeneration of descendants close to the mother trees, increasing the SGS of future generations. As a consequence, future generations may present in addition to a greater SGS, greater inbreeding due to the mating among related trees.

Encroaching deforestation, along with selective logging, mining, and agribusiness, are threatening the conservation of natural forests (Davidson et al., 2012; Kalamandeen et al., 2018). Understanding the genetic dynamics of economically important tropical species is necessary not only to determine the measures that must be taken to ensure environmental conservation, but also to assess species resilience, thus inferring their ability to survive under severe habitat conditions, especially in the face of climate change (Bocanegra-González et al., 2018). Given this scenario, the objectives of this study were to investigate the intrapopulation spatial genetic structure of a preserved $S$. macrophylla population in a managed forest located in Southwestern Amazon and examine the genetic parameters that underlie the concepts guiding conservation and management strategies.

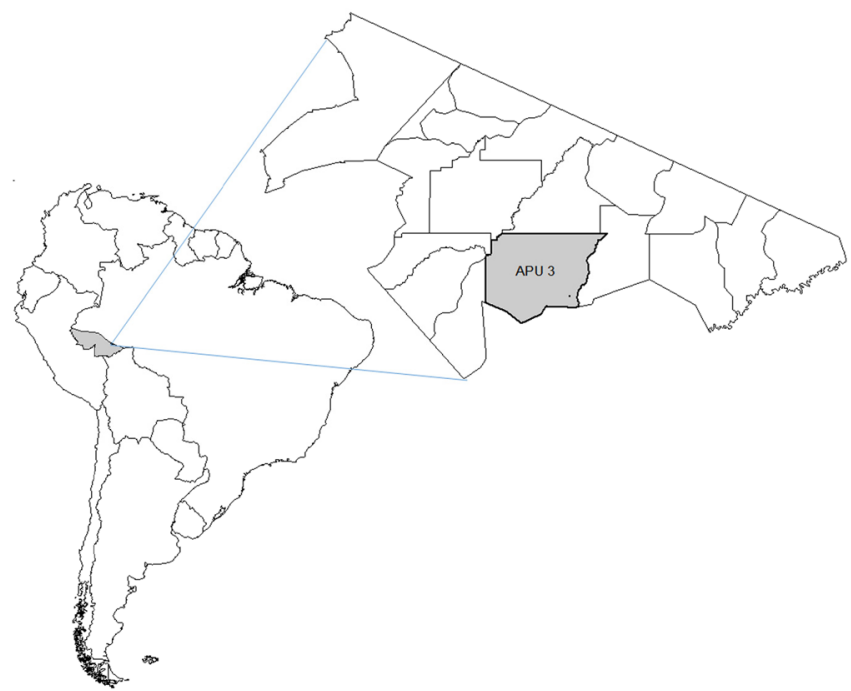

Fig. 1. Location of the Antimary State Forest (FEA), Acre State, Brazil, with the breakdowns of the annual production units (APU) and the location of APU 3 where the study was carried out within the FEA.

\section{Material and methods}

\subsection{Study area}

The study was conducted in the Southwestern Brazilian Amazon, in the Antimary State Forest (FEA), a region that covers the municipalities of Bujari and Sena Madureira in Acre, Brazil (Fig. 1). The climate type is Awi, with an average annual temperature of $25^{\circ} \mathrm{C}$ and annual precipitation of approximately $2000 \mathrm{~mm}$ (Alvares et al., 2014). The FEA is managed by the Acre state government and is part of a group of Sustainable Use Conservation Units (SNUC, 2000). The FEA forest management plan was approved in 1989 (Acre Seed Technology Foundation - FUNTAC, 1989) and in areas designated for forest management, logging has been carried out since 1999. In 2004, a forest concession system was adopted to regulate forest operations by timber companies and to benefit FEA communities. The study was carried out in Annual Production Unit (APU) 3 (Fig. 1), with a total area of 3970 ha, of which 2596 ha were logged in 2013 and in 2015 the area underwent lowintensity selective logging $\left(10-15 \mathrm{~m}^{3} \mathrm{ha}^{-1}\right)$. During the pre-logging forest inventory, all individuals with diameter at breast height $(\mathrm{DBH}) \geq 40 \mathrm{~cm}$ were mapped, measured and botanically identified by parabotanists. The productive potential of APU 3 was estimated at $104,932,890 \mathrm{~m}^{3}$ of wood based on the identification of 17,198 trees. In the APU management plan, three species were considered protected by law: chestnut (Bertholletia excelsa), mahogany (S. macrophylla), and rubber tree (Hevea brasiliensis).

\subsection{Tree selection}

During the pre-logging forest inventory, S. macrophylla were identified and data collected on DBH and total height $(\mathrm{H})$, with geographic coordinates mapped with a Global Positioning System (GPS Garmin 76sc). Data collection took place between August and November 2016. A total of 182 individuals with $\mathrm{DBH} \geq 40 \mathrm{~cm}$ were sampled, of which 83 ( $46 \%$ of the total population) were randomly selected for vascular exchange sample collection, covering an area of approximately 1650 ha. Based on these selected trees, leaf tissue samples (2 to 3 leaves) were collected from 187 juvenile individuals within a radius of $20 \mathrm{~m}$. The sampling intensity was contingent on the availability of juveniles, since natural regeneration was not found in the $20 \mathrm{~m}$ radius around all selected trees. Plant tissue samples were immediately placed in microtubes containing transport buffer $(300 \mu \mathrm{L} 2 \%$ CTAB; $700 \mu \mathrm{L}$ 
absolute ethanol), kept in a cooler on ice, then taken to the Morphogenesis and Molecular Biology Laboratory of Embrapa Acre, Rio Branco, Brazil. Samples were stored in a freezer at $-20^{\circ} \mathrm{C}$ until genomic DNA extraction.

\subsection{Genomic DNA extraction and microsatellite analysis}

Total genomic DNA was extracted from vascular exchange and leaf tissue samples of $S$. macrophylla following the protocol described by Doyle and Doyle (1990) with modifications. Tissue samples were macerated with an automatic homogenizer (Tissue Lyser ${ }^{\circledR}$ Qiagen) for $1 \mathrm{~min}$ and $30 \mathrm{sec}$ at a frequency of 30 Hertz. Total extracted DNA was diluted in ultrapure water to a concentration of $2 \mathrm{ng} / \mu \mathrm{L}$. The quantity and quality of genomic DNA was evaluated by horizontal gel-stained $1 \%$ agarose gel electrophoresis (Invitrogen ${ }^{\circledast}$ ) and compared to known molecular size standards (Invitrogen ${ }^{\circledR}$ ). For the genetic analysis, 12 pairs of microsatellite primers were used: sm05, sm07, sm08, sm12, sm18, sm20, sm28, sm36, sm39, sm43, sm48, and sm49 (Lemes et al., 2011). Amplification products were horizontally electrophoresed and visualized on 3\% agarose gel in 0.5X TBE buffer (Tris-borate, EDTA, pH 8.3) with $1 \mathrm{~kb}$ "Ladder" molecular standard (Gibco, MD). The amplified fragments were separated on $5 \%$ polyacrylamide denaturing gel in a vertical well containing $1 \mathrm{X}$ TBE buffer under $1600 \mathrm{~V}$ and $40 \mathrm{~mA}$. The electrophoresis run occurred for approximately two hours and thirty minutes. To color the gels, silver nitrate was used (Creste et al., 2001). Allele size was determined by comparison with standard molecular weight marker (10 bp "Ladder" - Invitrogen ${ }^{\circledast}$ ).

\subsection{Analysis of genetic diversity}

The genetic diversity of adult and juvenile individuals was estimated based on the following parameters using the FSTAT 2.9.3.2. software (Goudet, 1995): total number of alleles (K), allelic richness $(R)$, observed $\left(\mathrm{H}_{\mathrm{o}}\right)$ and expected $\left(\mathrm{H}_{\mathrm{e}}\right)$ heterozygosity. The mean fixation index $(F)$ was estimated and its statistical significance was calculated by permutation of alleles between individuals. However, as the estimate for juveniles may be biased due to an overestimation of gene frequencies from maternal alleles (each juvenile within a family receives at least one maternal allele), this index was estimated as described in Wadt et al. (2015). To test whether the estimated indices were significantly different between adults and juveniles, the Jackknife resampling method was used. The standard genetic differentiation $\left(\mathrm{G}_{\mathrm{st}}^{\prime}\right)$ between adults and juveniles was estimated based on the method described in Hedrick (2005).

\subsection{Paternity analysis}

Due to the fact that juveniles were sampled in the forest within a range of $20 \mathrm{~m}$ around the expected mother tree, we first carried out a maternity analysis, using all trees as putative mothers. Then, only juveniles assigned to mother trees were used to conduct the paternity analysis and estimate pollen flow. The maternity and paternity analyses, as well as the combined non-exclusion probability of the first parent $\left(\mathrm{P}_{1}\right)$, second parent $\left(\mathrm{P}_{2}\right)$, parent pair $\left(\mathrm{P}_{\mathrm{p}}\right)$, and identity $\left(\mathrm{Q}_{\mathrm{i}}\right)$ were estimated using the software CERVUS 3.0.7 (Kalinowski et al., 2007). Cryptic gene flow $\left(\mathrm{C}_{\mathrm{gf}}\right)$, or the probability of detecting a parent within the sample when it was not actually sampled, was estimated as described by Dow and Ashley (1996). Paternity analyses were based on the single-parent exclusion probability method between juveniles and adults (parent-mothers and father). Juveniles for which we did not identify either parent in the population were determined as originating from pollen and seed immigration. Juveniles with the same individual designated as both maternal and paternal parent were identified as resulting from self-fertilization (s) and the total outcrossing rate estimated by $(t=1-s)$. Outcrossing among unrelated $\left(t_{u}\right)$ and related $\left(t_{r}\right)$ individuals were determined by classifying juveniles based on estimates of the coancestry coefficient $\left(\Theta_{\mathrm{xy}}\right)$ between parents using the SPAGEDI 1.3 software (Hardy and Vekemans, 2002). Values of $\Theta_{\mathrm{xy}} \geq 0.1$ among assigned parent pairs were used to indicate that juveniles originated from mating among relatives (Ismail et al., 2014). To confirm the results of the parentage analysis, the average $\Theta_{x y}$ between juveniles and assigned parents was estimated. The mean, standard deviation, and minimum and maximum $\theta_{x y}$ within families of $S$. macrophylla adult individuals was also estimated. Spatial coordinates of adult individuals were used to estimate mean, standard deviation (SD), median, minimum and maximum pollen dispersal distances based on the Euclidean distance between two points. The effective pollination neighbor area $\left(\mathrm{A}_{\mathrm{ep}}=2 \pi \sigma^{2}\right)$, where $\sigma^{2}$ is the axial variance of pollen dispersal) and the effective pollen dispersal neighbor radius $\left(r_{\mathrm{ep}}=\sqrt[2]{\mathrm{A}_{\mathrm{ep}} / 3,1415}\right)$ were calculated according to Levin (1998).

\subsection{Analysis of mating system}

The juveniles assigned to mother trees by maternity analysis were grouped for each mother tree as an open-pollination family, totaling 15 families (ranging from 4 to 35 juveniles per family). The mating system at the population level and individually for each seed tree was assessed based on the numerical Expectation-Maximization (EM) method, using the MLTR software (Ritland, 2002). The estimated indices were: maternal fixation index $\left(\mathrm{F}_{\mathrm{m}}\right)$; multilocus $\left(\mathrm{t}_{\mathrm{m}}\right)$ and single-locus $\left(\mathrm{t}_{\mathrm{s}}\right)$ outcrossing rates; mating among related individuals $\left(t_{m}-t_{s}\right)$; correlation of self-fertilization $\left(r_{s}\right)$; and paternity correlation $\left(r_{p m}\right)$. To test for statistical significance of the indices, we used 1000 bootstrap resampling, with individuals as resampling units. The estimated parameters were used to calculate the effective number of pollen donors $\left(\mathrm{N}_{\mathrm{ep}}\right.$; Ritland, 1989). The mean coancestry coefficient $(\Theta)$ and variance effective population size $\left(\mathrm{N}_{\mathrm{e}}\right)$ within family and the number of seed trees necessary for seed collection (m), assuming that the objective is to retain an effective reference size of 150, were estimated based on Sebbenn (2006). The $95 \%$ confidence interval of the indices was estimated as described in Wadt et al. (2015).

\subsection{Association of genetic parameters with forest management}

Genetic parameters were integrated in to a management model that considers genetic diversity, coancestry between individuals, and spatial distribution of trees. The core collection approach identifies the genotypes that are representative of the analyzed population. Due to the fact that $S$. macrophylla is an endangered species and shows evidence of inbreeding depression, maintaining maximum genetic diversity is essential to avoid loss of alleles or genes related to species fitness. We chose the most conservative parameter, maintaining $100 \%$ of all detected alleles, as the purpose of this core collection is to ensure the efficient use of the genetic resource. To calculate the minimum number of individuals representing the entire genetic diversity of the native forest population core collection, the CoreFinder v.1.1 software (Policriti and Sgarro, 2011) was used as it is based on strategy $\mathrm{M}$ (Escribano et al., 2008) and does not use any preliminary stratification or data grouping. Considering that a core collection represents the allelic richness present in a population, this analysis may indicate the minimum sample size for future genetic studies on the species in the region. Intrapopulation spatial genetic structure (SGS) was also analyzed for adult individuals based on the coefficient of coancestry $\left(\Theta_{\mathrm{xy}}\right.$; Loiselle et al., 1995), using the SPAGEDI 1.3 software (Hardy and Vekemans, 2002). Nine distance classes between samples (100-5576 m) were used. Statistical significance was obtained by comparing the confidence interval limits to a probability of $95 \%$ of the average estimate for each distance class calculated by the permutating (1000 times) individuals between distance classes. The spatial location of the core collection genotypes were mapped to visualize their distribution throughout the reserve (APU 3). We also plotted the radius of the SGS 
Table 1

Genetic diversity and fixation index (F) for Swietenia macrophylla adults and juveniles in Southwestern Amazon.

\begin{tabular}{lllllll}
\hline Sample & $\mathrm{n}$ & $K$ & $\mathrm{R}_{\mathrm{S}}$ & $\mathrm{H}_{\mathrm{o}}$ & $\mathrm{H}_{\mathrm{e}}$ & $\mathrm{F}$ \\
\hline Adults & 83 & 98 & $10.3 \mathrm{a}$ & $0.767 \mathrm{a}$ & $0.806 \mathrm{a}$ & $0.048 \mathrm{a}$ \\
Juveniles & 187 & 92 & $9.3 \mathrm{~b}$ & $0.763 \mathrm{a}$ & $0.831 \mathrm{a}$ & $0.119 * \mathrm{~b}$ \\
Total & 270 & 105 & - & - & - & - \\
\hline
\end{tabular}

$\mathrm{n}$ is the sample size; $K$ is the total number of alleles; $\mathrm{R}_{\mathrm{s}}$ is the allelic richness; $\mathrm{H}_{\mathrm{o}}$ is the observed heterozygosity; $H_{e}$ is the expected heterozygosity, $\mathrm{G}_{\mathrm{st}}^{\prime}$ is the genetic differentiation between adults and juveniles $(0.247, \mathrm{P}<0.05)$. Different letters in the column indicate significant differences at $95 \%$ based on jackknife resampling among loci.

* $\mathrm{P}<0.05$

distance to determine the range (m) within which the distribution of individuals is not random, that is, in which individuals in close proximity may be related. Thus, the association of these parameters allowed for a visual representation of the modulation of gene flow on the genetic structure of the population.

\section{Results}

\subsection{Genetic diversity}

A large number of individuals ( $n=270$; 83 adults and 187 juveniles) were analyzed across the two age classes. Nine of the 12 microsatellite markers $(75 \%)$ were polymorphic and were therefore used to conduct the genetic analysis. For the nine polymorphic loci, a total of 105 alleles were observed in the total sample, with 98 present in adults and 92 in juveniles (Table 1 ). Mean allelic richness $(R)$ was significantly higher and fixation index $(F)$ was significantly lower in adults than juveniles. The $F$ value was significantly higher than zero for juveniles (0.119), suggesting selection against inbred individuals between the juvenile and adult stages. The standard genetic differentiation between adults and juveniles was significantly higher than zero $\left(\mathrm{G}_{\mathrm{st}}^{\prime}=0.247\right.$, $\mathrm{P}<0.05)\left(\mathrm{G}_{\mathrm{st}}^{\prime}=0.26\right)$, demonstrating that juveniles have a different genetic structure than adults.

\subsection{Parentage analyses}

The nine polymorphic loci showed low combined non-exclusion probability of the first parent $\left(\mathrm{P}_{1}=0.00123955\right)$, second parent $\left(\mathrm{P}_{2}=0.00002974\right)$, parent pair $\left(\mathrm{P}_{\mathrm{p}}=0.00000002\right)$, and identity $\left(Q_{i}=7.58^{-13}\right)$, resulting in a low probability of cryptic gene flow $\left(C_{g f}\right)$ for the first parent (0.09782), second parent (0.0247), and parent pair (0.000002). Eight (4.2\%) of the 187 sampled juveniles were not assigned to the expected mother tree within the $20 \mathrm{~m}$ radius, including two juveniles of family 1 and six juveniles of family 26 (Table 2). Of the remaining 179 juveniles, 75 (42\%) were assigned to a pollen donor within the study area. Four of the assigned 75 juveniles, were assigned the same mother tree as pollen donor, indicating a self-fertilization rate (s) of $2 \%$ and a total outcrossing rate $(t)$ of $98 \%$. The observed pollen dispersal distance ranged from 12 to $3905 \mathrm{~m}$, with a mean ranging among seed trees from 290 to $3236 \mathrm{~m}$ (overall mean of $1472 \mathrm{~m}$ ) and median ranging from 51 to $3454 \mathrm{~m}$ (overall mean of $1504 \mathrm{~m}$ ). Approximately $60 \%$ of pollen was dispersal up to $2000 \mathrm{~m}$ (Fig. 2). The mean effective pollination neighbor area $\left(\mathrm{A}_{\mathrm{ep}}\right)$ was also large $(792 \mathrm{ha})$, resulting in an effective pollination neighbor radius $\left(\mathrm{r}_{\mathrm{ep}}\right)$ of $1588 \mathrm{~m}$. In four seed trees we detected mating among relatives $\left(\mathrm{t}_{\mathrm{r}}\right)$, producing an overall $t_{\mathrm{r}}$ of $11 \%$ and an overall rate of mating among unrelated trees $\left(t_{u}\right)$ of $87 \%$. The mean coancestry among relatives $\left(\Theta_{\mathrm{r}}\right)$ was 0.17 , mean inbreeding from self-fertilization $\left(\mathrm{F}_{\mathrm{s}}\right)$ was 0.45 , mean inbreeding from mating among relatives $\left(\mathrm{F}_{\mathrm{r}}\right)$ was 0.09 , and the mean distance between related individuals $\left(D_{r}\right)$ was $406 \mathrm{~m}$, ranging from 51 to $2308 \mathrm{~m}$, with $78.9 \%$ of mating between related individuals occurring among trees up to $51 \mathrm{~m}$.

\subsection{Mating system}

The average population fixation index of seed trees $\left(\mathrm{F}_{\mathrm{m}}=0.04\right)$ was not significantly lower than zero (Table 3 ). However, the average juvenile population fixation index $\left(\mathrm{F}_{0}\right)$ was significantly higher than zero among families, ranging among families from -0.001 to 0.26 , with a mean of 0.12 . This suggests the occurrence of inbreeding. The mean multilocus outcrossing rate was high $\left(\mathrm{t}_{\mathrm{m}}=1.0\right.$, ranging among seed trees from 0.98 to 1.0 ), indicating that the species mainly reproduces by cross-fertilization. The mean mating among related individuals was low $\left(t_{m}-t_{s}=0.06\right)$, but significantly higher than zero. The paternity correlation $\left(\mathrm{r}_{\mathrm{pm}}=0.15\right)$ suggests $15 \%$ of full-sibs within family, ranging among seed trees from 6 to $22 \%$. The mean effective number of pollen donors $\left(\mathrm{N}_{\mathrm{ep}}\right)$ was 6.7 , showing that approximately seven adult individuals acted as pollen donors for this population. The coancestry within family $(\Theta=0.149)$ was higher and the effective population size $\left(\mathrm{N}_{\mathrm{e}}=2.73\right)$ lower than that expected in random mating populations $\left(\Theta=0.125 ; \mathrm{N}_{\mathrm{e}}=4\right)$. The number of trees $(m)$ for collection of noninbred seeds was estimated at 55 (95\% CI: $52-59$ ), which is $66.3 \%$ (83 trees) to the number of trees representing the entire genetic diversity of the study population.

\subsection{Association of genetic parameters with forest management}

Spatial genetic structure (SGS) was detected for adult individuals up to $300 \mathrm{~m}$, with values decreasing to non-significant in the upper distance classes (Fig. 3). The core collection consisted of 42 (50.6\%) adult individuals across an area of 1650 ha (Fig. 4). These individuals should be included in seed collection and as pollen donors as they represent $100 \%$ of the total detected genetic diversity. The graphical representation (Fig. 4) shows the radius area of effective genetic influence of each tree resulted in overlapping areas. Each genotype in the core collection had two to five trees within the co-ordination radius that had some degree of kinship with the central plant.

\section{Discussion}

\subsection{Genetic diversity and inbreeding}

The studied $S$. macrophylla population presented high genetic diversity in terms of heterozygosity for adult $\left(\mathrm{H}_{\mathrm{o}}=0.767 ; \mathrm{H}_{\mathrm{e}}=0.82\right)$ and juvenile $\left(\mathrm{H}_{\mathrm{o}}=0.763 ; \mathrm{H}_{\mathrm{e}}=0.81\right)$ individuals, with values generally greater than those reported in other studies on the species in the Brazilian Amazon using microsatellite markers $\left(\mathrm{H}_{\mathrm{o}}=0.75, \mathrm{H}_{\mathrm{e}}=0.78\right.$, Lemes et al., 2003; $\mathrm{H}_{\mathrm{o}}=0.63-0.80, \mathrm{H}_{\mathrm{e}}=0.71-0.84$, Degen et al., 2013) and those reported for Mesoamerica $\left(H_{0}=0.56, H_{e}=0.66\right.$, Novick et al., 2003; $H_{0}=0.44-0.74$, Breed et al., 2012). These results reinforce the suggestion that the greatest levels of allelic diversity are in the Brazilian Amazon (Trujillo-Sierra et al., 2013). This population in Acre is at the center of the species distribution, and previous studies have suggested that the region is a center of diversity for many Amazonian species. However, the allelic richness (R) and fixation index $(F)$ suggest a significant loss of diversity in the juvenile stratum and the emergence of inbreeding in the younger cohort.

The absence of inbreeding in adult individuals and its detection in juveniles suggests the occurrence of inbreeding depression which can cause the mortality of some inbred juveniles, thus decreasing the rate of inbreeding between juvenile and adult life stages. Inbreeding in juveniles can be explained by the observed mating among related individuals $\left(\mathrm{t}_{\mathrm{m}}-\mathrm{t}_{\mathrm{s}}=0.06, \mathrm{t}_{\mathrm{r}}=0.11\right)$, which would lead to a lower rate of survival and increased risks for the species due to inbreeding depression. There is also evidence that inbreeding depression in tropical tree species is more pronounced in the early stages of life (seeds, seedlings, and juveniles), with adult trees showing lower levels of 
Table 2

Estimates of pollen immigration $\left(\mathrm{m}_{\mathrm{p}}\right)$ and dispersal distance, and mating system indices for each Swietenia macrophylla family.

\begin{tabular}{|c|c|c|c|c|c|c|c|c|c|c|c|c|c|c|c|c|}
\hline \multirow[b]{2}{*}{ Tree } & \multirow[b]{2}{*}{$\mathrm{n}$} & \multirow[b]{2}{*}{$\mathrm{m}_{\mathrm{p}}(\%)$} & \multirow[b]{2}{*}{ Assigned (\%) } & \multirow[b]{2}{*}{$s(\%)$} & \multirow[b]{2}{*}{$t(\%)$} & \multicolumn{3}{|l|}{ Distance (m) } & \multirow[b]{2}{*}{$\mathrm{A}_{\mathrm{ep}}$ (ha) } & \multirow[b]{2}{*}{$\mathrm{r}_{\mathrm{ep}}(\mathrm{m})$} & \multirow[b]{2}{*}{$\mathrm{t}_{\mathrm{r}}(\%)$} & \multirow[b]{2}{*}{$\Theta_{\mathrm{r}}$} & \multirow[b]{2}{*}{$\mathrm{t}_{\mathrm{u}}(\%)$} & \multirow[b]{2}{*}{$\mathrm{F}_{\mathrm{s}}$} & \multirow[b]{2}{*}{$\mathrm{F}_{\mathrm{r}}$} & \multirow[b]{2}{*}{$\mathrm{D}_{\mathrm{r}}(\mathrm{m})$} \\
\hline & & & & & & Mean \pm SD & $\operatorname{Min} / \max$ & Median & & & & & & & & \\
\hline 1 & 35 & $23(66)$ & $12(34)$ & 0 & $35\left(\begin{array}{lll}1 & 0 & 0\end{array}\right)$ & $1417 \pm 667$ & $786 / 2279$ & 830 & 257 & 904 & 0 & - & $35\left(\begin{array}{lll}1 & 0 & 0\end{array}\right)$ & - & - & - \\
\hline 67 & 17 & $5(29)$ & $12(71)$ & $1(6)$ & $16(94)$ & $586 \pm 686$ & $51 / 1733$ & 51 & 269 & 925 & $6(35)$ & 0.15 & $10(59)$ & 0.23 & 0 & 51 \\
\hline 26 & 18 & $5(28)$ & $13(72)$ & 0 & $18\left(\begin{array}{lll}1 & 0 & 0\end{array}\right)$ & $486 \pm 925$ & $39 / 2550$ & 51 & 497 & 1257 & $9(5)$ & 0.15 & $9(5)$ & - & 0.12 & 51 \\
\hline 12 & 12 & $7(58)$ & $5(42)$ & $1(8)$ & $11(92)$ & $2268 \pm 768$ & $1504 / 3240$ & 1833 & 278 & 940 & 0 & - & $11(92)$ & 0.42 & - & - \\
\hline 33 & 8 & 7 (87) & $1(13)$ & 0 & $8\left(\begin{array}{lll}1 & 0 & 0\end{array}\right)$ & $1504 \pm 0$ & 1504 & - & 0 & - & 0 & - & $8\left(\begin{array}{lll}1 & 0 & 0\end{array}\right)$ & - & - & - \\
\hline 45 & 13 & $4(31)$ & 9 (69) & 0 & $13\left(\begin{array}{lll}1 & 0 & 0\end{array}\right)$ & $1481 \pm 1014$ & $485 / 3118$ & 1744 & 267 & 921 & 0 & - & $13\left(\begin{array}{lll}1 & 0 & 0\end{array}\right)$ & - & - & - \\
\hline 24 & 9 & $6(67)$ & $3(33)$ & $1(11)$ & $8(89)$ & $2987 \pm 91$ & $2922 / 3051$ & 2922 & 3 & 91 & 0 & - & $8(89)$ & 0.40 & - & - \\
\hline 53 & 7 & $3(43)$ & $4(57)$ & 1 (14) & $6(86)$ & $2547 \pm 6$ & $2540 / 2550$ & 2550 & 0 & 7 & 0 & - & $6(86)$ & 0.76 & - & - \\
\hline 50 & 4 & $3(75)$ & $1(25)$ & 0 & $4\left(\begin{array}{lll}1 & 0 & 0\end{array}\right)$ & $3236 \pm 0$ & 3236 & - & 0 & - & 0 & - & $4\left(\begin{array}{lll}1 & 0 & 0\end{array}\right)$ & - & - & - \\
\hline 41 & 9 & $8(89)$ & $1(11)$ & 0 & $9\left(\begin{array}{lll}1 & 0 & 0\end{array}\right)$ & $2279 \pm 0$ & 2279 & - & 0 & - & 0 & - & $9\left(\begin{array}{lll}1 & 0 & 0\end{array}\right)$ & - & - & - \\
\hline 14 & 13 & $10(77)$ & $3(23)$ & 0 & $13\left(\begin{array}{lll}1 & 0 & 0\end{array}\right)$ & $2916 \pm 237$ & $2779 / 3189$ & 2779 & 979 & 1765 & 0 & - & $13\left(\begin{array}{lll}1 & 0 & 0\end{array}\right)$ & - & - & - \\
\hline 2 & 12 & $9(75)$ & $3(25)$ & 0 & $12\left(\begin{array}{lll}1 & 0 & 0\end{array}\right)$ & $2768 \pm 1595$ & $945 / 3905$ & 3454 & 1065 & 1841 & 0 & - & $12\left(\begin{array}{lll}1 & 0 & 0\end{array}\right)$ & - & - & - \\
\hline 47 & 5 & $4(8)$ & $1(2)$ & 0 & $5\left(\begin{array}{lll}1 & 0 & 0\end{array}\right)$ & $290 \pm 0$ & 290 & - & 0 & 0 & 0 & - & $5\left(\begin{array}{lll}1 & 0 & 0\end{array}\right)$ & - & - & - \\
\hline 65 & 4 & $1(25)$ & $3(75)$ & 0 & $4\left(\begin{array}{lll}1 & 0 & 0\end{array}\right)$ & $2122 \pm 322$ & $1751 / 2308$ & 2308 & 43 & 371 & $2(5)$ & 0.25 & $2(5)$ & - & 0.12 & 2308 \\
\hline 73 & 13 & $9(69)$ & $4(31)$ & 0 & $13\left(\begin{array}{lll}1 & 0 & 0\end{array}\right)$ & $2002 \pm 1362$ & $12 / 3063$ & 2627 & 875 & 1669 & $2(15)$ & 0.19 & $11(85)$ & - & 0.17 & 1160 \\
\hline Total & 179 & $104(58)$ & $75(42)$ & $4(2)$ & $175(98)$ & $1472 \pm 1144$ & $12 / 3905$ & 1504 & 792 & 1588 & $19(11)$ & 0.17 & $156(87)$ & 0.45 & 0.09 & 406 \\
\hline
\end{tabular}

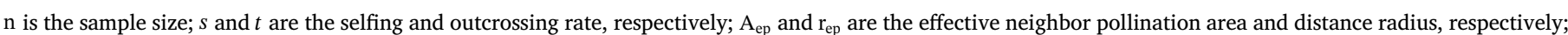

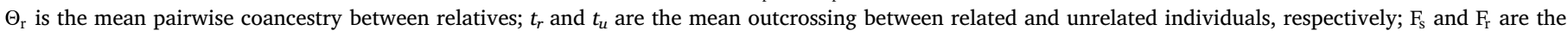

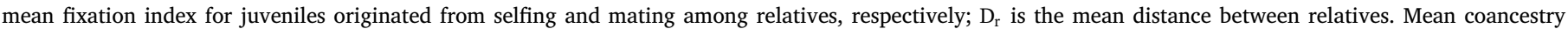
between juvenile-mother: $\Theta_{\mathrm{JM}} \pm \mathrm{SD}(0.243 \pm 0.110)$; Mean coancestry between juvenile-father: $\Theta_{\mathrm{JF}} \pm \mathrm{SD}(0.140 \pm 0.094)$. SD is the standard deviation.

inbreeding (Duminil et al., 2016; Tambarussi et al., 2017; Moraes et al., 2018; Pupim et al., 2019). The higher number of homozygotes and greater levels of inbreeding detected in juveniles is likely a transient natural phenomenon that will be mitigated by environmental pressure as the juvenile cohort transitions to older life stages. Thus, the inbreeding observed in juveniles is likely to decrease through natural evolutionary dynamics. However, although inbreeding may be transient when the juvenile stratum is recruited, the significant loss of alleles is a sign of susceptibility of the genetic diversity of the species. Therefore, the juvenile stratum presents a transient and vulnerable genetic profile, which underscores the need for greater attention given to the species in terms of conservation and management.

\subsection{Pollen dispersal distance}

The long range pollen dispersal distance detected through genetic analysis represents the evolutionary history resulting from the low population density of $S$. macrophylla in association with pollination by non-specialist insects, as pollinators must travel long distances to reach co-specific individuals (White et al., 2002; André et al., 2008). This reinforces that long-distance pollination by generalist insects is effective and necessary for maintaining the species' genetic diversity, as pollinator behavior partly determines the distance over which pollen can be dispersed (Dick et al., 2008). Bees and moths, the main pollinators of $S$. macrophylla, are capable of long-distance pollen dispersal and can transfer pollen between co-specific trees over distances in the kilometers (Ghazoul, 2005). A mean pollen dispersal distance of $576 \mathrm{~m}$ was reported for $S$. macrophylla in logged forest areas in Bolivia (Sebbenn et al., 2012). Similarly, this result was attributed to the density of the species which decreased after selective logging. Pollen dispersal over long distances was also reported for Swietenia humilis $(2014 \mathrm{~m})$, with the average dispersal distance greater in a disturbed environment (Rosas et al., 2011). Another study on S. humilis showed pollen movement over distances greater than $4.5 \mathrm{~km}$ (White et al., 2002), which indicates resilience of the species to disturbances and corroborates the results of the present study.

Disturbances alter ecological interactions and can have a particular effect on pollinators (Lowe et al., 2003). There is evidence that pollen dispersal patterns of tropical tree species are influenced by dispersal vectors, population density, floral synchrony, mechanisms that reduce the rate of self-fertilization, as well as edaphoclimatic factors and anthropogenic interference (Dick et al., 2008; Degen and Sebbenn, 2014). Although forest logging operations can alter patterns of spatial distribution and structure of the forest, affecting the behavior of the species' pollinators (Lowe et al., 2003; Breed et al., 2012), in the present study this may not have occurred due to the low intensity of logging and the use of reduced impact logging techniques (Carvalho et al., 2017) for tree felling and log extraction. Studies in the Brazilian Amazon have found a reduction in pollen immigration rates following selective logging practices (André et al., 2008; Lacerda et al., 2008; Carneiro et al., 2011; Breed et al., 2012). However, unlike these previous studies, the forest management that occurred in 2013 at APU3 did

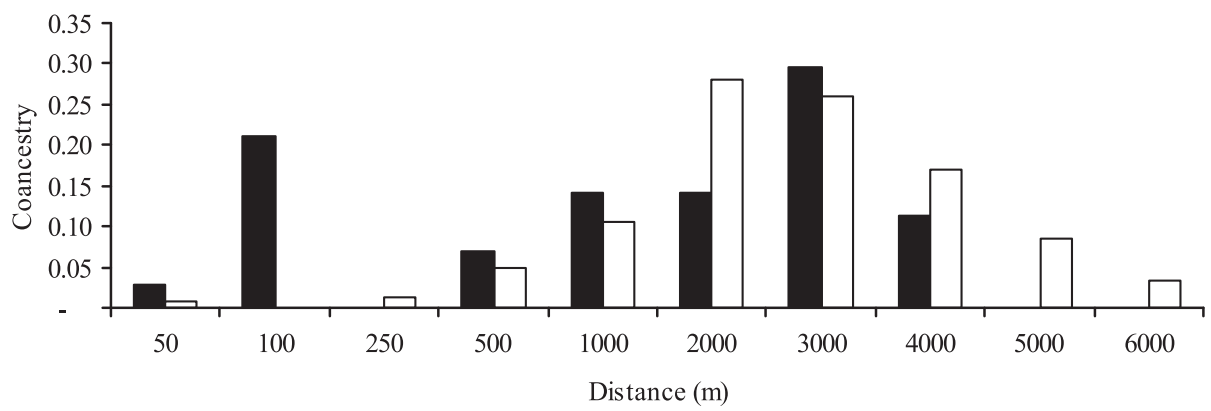

Pollen $\square$ Distance all trees

Fig. 2. Effective pollen dispersal distance and geographical distance among adult individuals of Swietenia macrophylla. 
Table 3

Mean and 95\% confidence interval (95\% CI) for mating system indices of Swietenia macrophylla in Southwestern Amazon.

\begin{tabular}{|c|c|c|c|c|c|c|c|c|c|c|}
\hline Tree & $\mathrm{F}_{\mathrm{m}}$ & $\mathrm{n}$ & $\mathrm{H}_{\mathrm{o}}$ & $\mathrm{F}_{\mathrm{o}}$ & $\mathrm{t}_{\mathrm{m}}(\mathrm{SD})$ & $\mathrm{t}_{\mathrm{m}}-\mathrm{t}_{\mathrm{s}}(\mathrm{SD})$ & $\mathrm{r}_{\mathrm{pm}}(\mathrm{SD})$ & $\mathrm{N}_{\mathrm{ep}}$ & $\Theta$ & $\mathrm{N}_{\mathrm{e}}$ \\
\hline 1 & -0.10 & 35 & 0.79 & $0.05^{*}$ & $1.00(0.01)$ & $0.02(0.01)$ & $0.06(0.01)$ & 18.2 & 0.132 & 3.49 \\
\hline 2 & -0.04 & 17 & 0.73 & $0.12^{*}$ & $1.00(0.01)$ & $0.16(0.05)$ & $0.22(0.12)$ & 4.6 & 0.153 & 2.83 \\
\hline 3 & -0.05 & 18 & 0.69 & $0.18^{*}$ & $1.00(0.01)$ & $0.07(0.03)$ & $0.17(0.08)$ & 6.1 & 0.146 & 2.94 \\
\hline 4 & -0.16 & 12 & 0.82 & 0.01 & $1.00(0.01)$ & $0.04(0.01)$ & $0.20(0.10)$ & 5.1 & 0.150 & 2.79 \\
\hline 5 & 0.05 & 8 & 0.78 & $0.08^{*}$ & $0.99(0.01)$ & $0.05(0.01)$ & $0.21(0.08)$ & 4.7 & 0.161 & 2.41 \\
\hline 6 & 0.13 & 13 & 0.73 & $0.13^{*}$ & $1.00(0.01)$ & $0.08(0.01)$ & $0.19(0.03)$ & 6.0 & 0.165 & 2.55 \\
\hline 7 & 0.06 & 9 & 0.72 & $0.15^{*}$ & $0.99(0.01)$ & $0.09(0.04)$ & $0.12(0.05)$ & 8.7 & 0.150 & 2.54 \\
\hline 8 & 0.04 & 7 & 0.70 & $0.16^{*}$ & $0.99(0.01)$ & $0.09(0.04)$ & $0.10(0.01)$ & 10.3 & 0.146 & 2.40 \\
\hline 9 & 0.07 & 4 & 0.61 & $0.26^{*}$ & $0.97(0.01)$ & $0.10(0.02)$ & $0.11(0.02)$ & 9.3 & 0.155 & 1.83 \\
\hline 10 & -0.09 & 9 & 0.76 & $0.09 *$ & $0.99(0.01)$ & $0.05(0.01)$ & $0.11(0.01)$ & 9.1 & 0.141 & 2.69 \\
\hline 11 & -0.11 & 13 & 0.78 & $0.07 *$ & $1.00(0.01)$ & $0.06(0.02)$ & $0.09(0.01)$ & 11.0 & 0.137 & 2.98 \\
\hline 12 & -0.01 & 12 & 0.68 & $0.08^{*}$ & $1.00(0.01)$ & $0.12(0.03)$ & $0.17(0.09)$ & 5.9 & 0.147 & 2.78 \\
\hline 13 & 0.12 & 5 & 0.76 & -0.01 & $0.98(0.01)$ & $0.05(0.02)$ & $0.22(0.09)$ & 4.5 & 0.176 & 2.08 \\
\hline 14 & 0.46 & 4 & 0.50 & $0.25^{*}$ & $0.97(0.01)$ & $0.11(0.02)$ & $0.22(0.11)$ & 4.6 & 0.232 & 1.51 \\
\hline 15 & 0.21 & 13 & 0.56 & $0.16^{*}$ & $1.00(0.01)$ & $0.13(0.02)$ & $0.17(0.06)$ & 5.8 & 0.178 & 2.40 \\
\hline Overall & 0.04 & 179 & & 0.12 & 1.0 & 0.06 & 0.15 & 6.7 & 0.149 & 2.73 \\
\hline $95 \%$ CI & $-0.04-0.12$ & & & & $1.0-1.0$ & $0.03-0.07$ & $0.11-0.17$ & $5.9-9.2$ & $0.149-0.163$ & $2.53-2.91$ \\
\hline
\end{tabular}

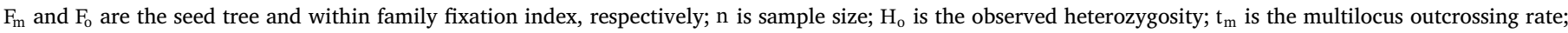

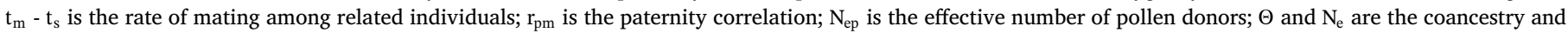
effective size within families, respectively.

* $\mathrm{P}<0.05$. Selfing correlation $\left(\mathrm{r}_{\mathrm{s}}\right): 0.110(0.105-0.115)$; Number of seed trees $(\mathrm{m}): 55$ (52-59).

not include $S$. macrophylla. Thus, although the analyzed population was not fragmented, selective logging may have affected pollinator behavior which can cause a loss of alleles (Sebbenn et al., 2008).

\subsection{Mating system}

The estimated high outcrossing rate $(>0.85)$ indicates that the species is predominantly allogamous, corroborating previous studies on the species (Loveless et al., 2003; Lemes et al., 2007; Breed et al., 2012; Sebbenn et al., 2012). We observed outcrossing variation among trees, and it is possible that some trees produce seeds by both self-fertilization and outcrossing. Because it is a monoecious species, self-pollination is possible, but dichogamy can occur (Styles, 1972; Lemes et al., 2007), which is a mechanical barrier that favors outcrossed reproduction.

However, although reproduction by outcrossing was predominate, mating was not random due to the occurrence of mating among related trees $\left(\mathrm{t}_{\mathrm{m}}-\mathrm{t}_{\mathrm{s}}=0.06, \mathrm{t}_{\mathrm{r}}=0.11\right)$, and some mating was correlated $\left(\mathrm{r}_{\mathrm{pm}}=0.15\right)$ with juveniles originating from mating between the same parent pair, resulting in full-sibs. These results confirm that there are some inbred juveniles within families, from self-fertilization and/or mating among related individuals, and also show that within families there are mixtures of levels of relatedness (self-sibs, half-sibs, full-sibs, and self-half-sibs). Both inbreeding and mixtures of relatedness within open-pollinated families is a common pattern that has been reported for several tropical tree species (Breed et al., 2012; Giustina et al., 2018; Postacheff et al., 2019; Solís-Hernández and Eric Fuchs, 2019). The occurrence of biparental inbreeding due to mating among relatives supports the observed occurrence of spatial genetic structure (SGS) among adult individuals (up to $300 \mathrm{~m}$ ). The paternity analysis showed that the greatest proportion of mating among relatives occurred up to a distance of $51 \mathrm{~m}(78.9 \%)$, but reached up to $2308 \mathrm{~m}$, also indicating that related trees occur over long distances. The low level of interbreeding between related individuals reinforces the need for conservation of the genetic diversity of the species.

Correlated mating can be attributed to the behavior of pollen dispersal vectors (bees and moths), suggesting that they are visiting many flowers of the same tree before flying on to the next tree; it can also be related to the reproductive population density, which is determined by individual flowering phenology (Lemes et al., 2007; Breed et al., 2012; Sebbenn et al., 2012). Our results indicate that a greater mean effective number of pollen donors $\left(\mathrm{N}_{\mathrm{ep}}=6.7\right)$ fertilized the seed trees than that reported for a logged $S$. macrophylla population in Brazil $\left(\mathrm{N}_{\mathrm{ep}}=2.3\right.$, Lemes et al., 2007), as well as that reported for Mesic isolated populations in Central America $\left(\mathrm{N}_{\mathrm{ep}}=1 / 0.445=2.2\right.$, Breed et al., 2012). Nevertheless, our results are similar to those reported for dry forest populations in Central America $\left(\mathrm{N}_{\mathrm{ep}}=1 / 0.153=6.5\right.$, Breed et al., 2012). These results indicate that the proposed logging of $S$. macrophylla populations in APU3 of the Antimary State Forest may limit pollen dispersal due to a reduction in population density caused by logging activities (opening of clearings, trails, secondary roads, etc.) but favor anemochoric seed dispersal over long distances (Grogan et al., 2008). Breed et al. (2012) identified an effective reduction in the

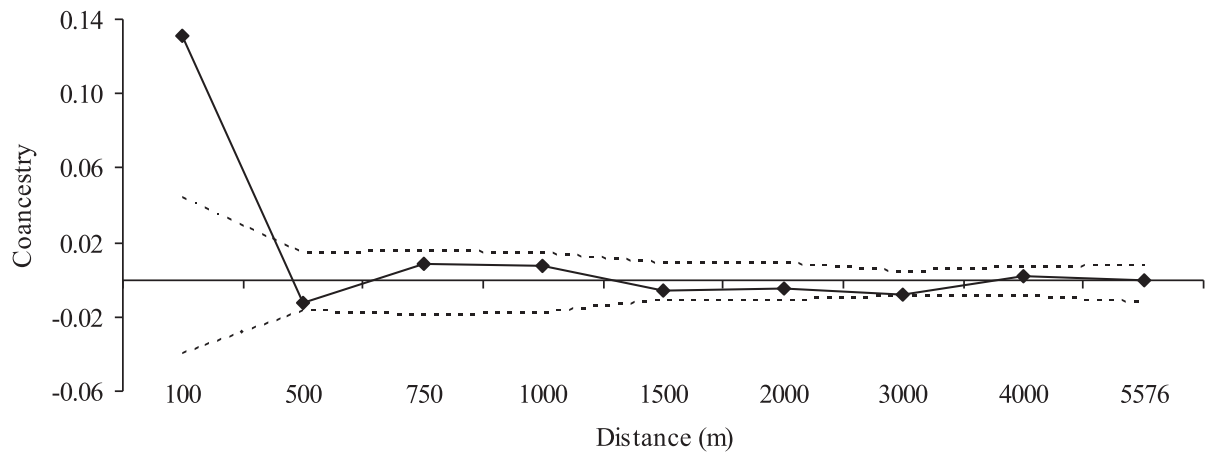

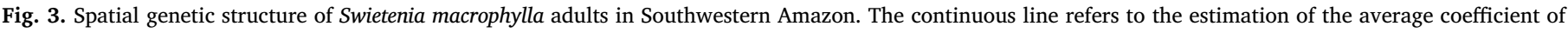
coancestry and the dotted lines refer to the estimated confidence interval $(\mathrm{P}<0.05)$ of the hypothesis of absence of spatial genetic structure $\left(\mathrm{H}_{0}\right.$ : $\left.\Theta_{x y}=0\right)$. 


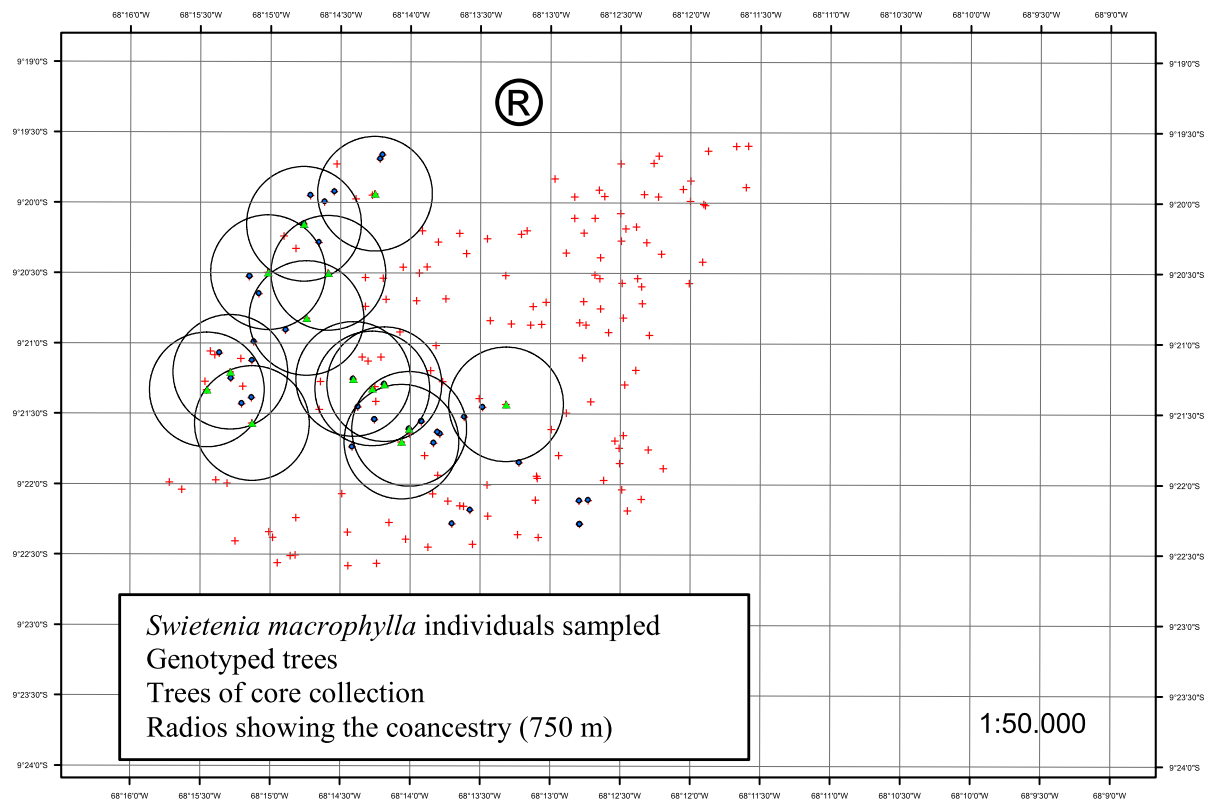

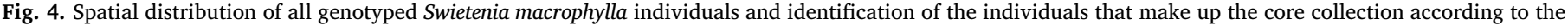
representative radius of the coancestry analysis $(750 \mathrm{~m})$.

density of $S$. macrophylla pollen donors as a result of habitat fragmentation. In habitats that have experienced anthropogenic interference, particularly in the case of isolated trees, changes may occur that reflect disruptions to the reproductive pattern, reducing the outcrossing rate and increasing paternity correlation (Lowe et al., 2003; Breed et al., 2012). The crossing rate and paternity correlation detected herein were similar to the values found for populations in remnants or patches of forests in Central America and not for isolated individuals (Breed et al., 2012). Thus, despite detection of a decrease in allelic richness and heterozygosity in juveniles, the reproductive biology pattern reflects a resistance (buffering effect) to the anthropogenic interference of selective management in the study area.

Due to the observed mating patterns, our results indicate that 55 seed trees are required for seed collection to retain progeny array samples for genetic conservation, breeding, and environmental reforestation. This value is consistent with values $(\leq 45)$ reported for other tropical tree species (Sebbenn, 2006; Lacerda et al., 2008; Carneiro et al., 2011; Manoel et al., 2015; Degen and Sebbenn, 2014; Giustina et al., 2018; Postacheff et al., 2019).

\subsection{Association of genetic parameters with forest management}

All parameters estimated from molecular markers, including genetic diversity, inbreeding, gene flow, outcrossing rate, and SGS, are key to understanding the genetics of $S$. macrophylla in order to develop strategies for conservation. Consistent with the pollen dispersal pattern and low density of the species, the adult population studied herein is genetically and spatially structured. SGS in natural tree populations is shaped by spatial distribution, natural selection, and seed and pollen dispersal patterns (Silva et al., 2011; Dering et al., 2015). Short-distance seed dispersal resulted in the structuring of $S$. macrophylla genotypes due to an increase in the mean coancestry between pairs of proximal individuals. Mating among near neighbour related trees results in biparental inbreeding in juveniles.

Low-density populations generally show less structure and often an absence of SGS (Alcalá et al., 2014, , 2015). The observed pattern of genetic structuring in S. macrophylla was mitigated by the long-distance pollination activities of generalist insects.

The detection of genetic structure in $S$. macrophylla is consistent with the observed long-range pollen dispersal and possibly associated with localized seed dispersal. Although seeds are dispersed via anemochory, average distances of $S$. macrophylla seed dispersal reach only 32 to $36 \mathrm{~m}$, with a maximum distance of $80 \mathrm{~m}$ from the mother tree (Gullison et al., 1996; Loveless et al., 2003; Alcalá et al., 2014). However, seed dispersal patterns are strongly influenced by climate factors and forest density and may reach up to $100 \mathrm{~m}$ from the mother tree (Grogan et al., 2008). Limited seed dispersal increases the likelihood of kinship between proximal individuals; this may lead to interbreeding in subsequent generations if such individuals flower synchronically and pollinating vectors fly between co-specific trees (Wadt et al., 2015).

Seed tree selection for pollen donors and seed banks that is based on the core collection is recommended for in situ conservation of $S$. macrophylla and is essential for maintaining genetic variability. In terms of ex situ conservation, the seed trees that make up the core collection are important for the development of seedlings to form germplasm banks that are representative of the diversity of this South American population. Therefore, the association of genetic parameters of the core collection and SGS may contribute to the development of collection strategies in new areas. Based on our results, seed collection for $S$. macrophylla conservation in the study area should be conducted with at least $750 \mathrm{~m}$ between seed trees in order to avoid collection from inbred and related individuals. This result is essential to inform strategies for ex situ and in situ genetic conservation, environmental improvement and reforestation, and identifying the diversity of seed trees.

The inclusion of $S$. macrophylla on the list of species approved for exploitation in the next cutting cycle will reduce the effective population size and have a negative impact on the genetic diversity of the resource. The results presented herein and in previous studies confirm that the species requires cross breeding for its maintenance, while also showing low levels of outcrossing between related individuals. Logging may seriously increase the risk of genetic erosion and species or population extinction due to a lack of adaptive ability. Swietenia macrophylla individuals serve as seed carriers and pollen donors that contribute ecologically and genetically to the maintenance of gene flow and effective population size. Because it is a low-density, threatened species that shows difficulty establishing natural regeneration in the area (Barros et al., 2019), and based on the availability and interpretation of genetic data provided herein and elsewhere, it is recommended that $S$. macrophylla remains preserved in its areas of natural occurrence. 
In this study we did not collected genetic material before logging, thus our data does not enable us to compare pre- and post-logging scenarios. As such, we could not attribute the observed inbreeding in the juvenile populations to the forest management system used in the study area. However, the relatively low impact of forest operations, the preservation of the entire adult $S$. macrophylla population, and the observed long distances of pollen dispersal, are strong indicators that inbreeding detected in juveniles is a natural occurrence. Nevertheless, we do not recommend the harvesting of $S$. macrophylla in the next cutting cycle. Based on our results and the actual status of the species as endangered, we instead recommend the implementation of strategies for ex situ and in situ genetic conservation such as seed collection from selected seed trees and silvicultural treatments such as the use of artificial regeneration in logged areas (e.g., d'Oliveira, 2000).

\section{CRediT authorship contribution statement}

Sabrina Silva de Oliveira: Data curation, Writing - original draft. Tatiana Campos: Conceptualization, Methodology, Writing - original draft. Alexandre Magno Sebbenn: Software, Visualization, Writing review \& editing, Investigation. Marcus Vinicio Neves d'Oliveira: Supervision, Writing - original draft.

\section{Declaration of Competing Interest}

The authors declare that they have no known competing financial interests or personal relationships that could have appeared to influence the work reported in this paper.

\section{Acknowledgements}

We thank the Federal University of Acre (UFAC), Embrapa Acre, and in particular the Laboratory of Morphogenesis and Molecular Biology for the logistical support and infrastructure and the availability of equipment for analysis. We acknowledge Coordenação de Aperfeiçoamento de Pessoal de Nível Superior (CAPES) for granting a scholarship and the Conselho Nacional de Desenvolvimento Científico e Tecnológico (CNPq) for their support of Brazilian scientific and technological development. Research fellowships were provided by CNPq to Alexandre M. Sebbenn and Tatiana de Campos. We also thank Dr. Evelyn Nimmo for editing the English of the manuscript.

\section{Appendix A. Supplementary material}

Supplementary data to this article can be found online at https:// doi.org/10.1016/j.foreco.2020.118040.

\section{References}

Alcalá, R.E., Alonso, R.L., Gutiérrez-Granados, G., 2014. Seed shadow of Swietenia mac rophylla remnant trees in a Mexican rainforest: Implications for forest management. Bot. Sci. 92, 599-605. https://doi.org/10.17129/botsci.137.

Alcalá, R.E., De La Cruz, S., Gutiérrez-Granados, G., 2015. Genetic structure and genetic diversity of Swietenia macrophylla in areas subjected to selective logging in quintana roo, Mexico. Bot. Sci. 93, 819-828. https://doi.org/10.17129/botsci.256.

Alvares, C.A., Stape, J.L., Sentelhas, P.C., Moraes, J.L., Sparovek, G., 2014. Koppen's climate classification map for Brazil. Meteorol. Z. 22, 711-728. https://doi.org/10. 1127/0941-2948/2013/0507.

André, T., Lemes, M.R., Grogan, J., Gribel, R., 2008. Post-logging loss of genetic diversity in a mahogany (Swietenia macrophylla King, Meliaceae) population in Brazilian Amazonia. For. Ecol. Manage. 255, 430-1345. https://doi.org/10.1016/j.foreco. 2007.09.055.

Arruda, C.C.B., Silva, M.B., Sebbenn, A.M., Kanashiro, M., Lemes, M.R., Gribel, R., 2015. Mating system and genetic diversity of progenies before and after logging: a case study of Bagassa guianensis (Moraceae), a low-density dioecious tree of the Amazonian forest. Tree Genet. Genome. 11, 3. https://doi.org/10.1007/s11295-0150837-2.

Baldauf, C., Ciampi-Guillardi, M., dos Santos, F.A.M., Souza, A.P., Sebbenn, A.M., 2013. Tapping latex and alleles? The impacts of latex and bark harvesting on the genetic diversity of Himatanthus drasticus (Apocynaceae). For. Ecol. Manage. 310, 434-441. https://doi.org/10.1016/j.foreco.2013.08.049.
Barros, Q.S., d'Oliveira, M.V.N., Oliveira, L.C., 2019. Regeneração natural do mogno (Swietenia macrophylla King) em área manejada na Amazônia Sul-Ocidental. Rio Branco: Embrapa (Embrapa Acre, Circular técnica, n.76).

Bawa, K.S., Perry, D.R., Beach, J.H., 1985. Reproductive biology of tropical lowland rain forest trees. I. Sexual systems and incompatibility mechanisms. Am. J. Bot. 72, 331-345. https://doi.org/10.1002/j.1537-2197.1985.tb05357.x.

Bocanegra-González, K.T., Thomas, E., Guillemin, M., Carvalho, D., Gutiérrez, J.P., Caicedo, C.A., Higuita, L.G.M., Becerra, L.A., González, M.A., 2018. Genetic diversity of Ceiba pentandra in Colombian seasonally dry tropical forest: implications for conservation and management. Biol. Conserv. 227, 29-37. https://doi.org/10.1016/ j.biocon.2018.08.021.

Brazil., 2015. Instrução normativa $\mathrm{n}^{\circ} 1$, de 12 de fevereiro de 2015. Regulamenta a exploração comercial de madeira da flora que integra a Lista Nacional Oficial de Espécies da Flora Ameaçadas de Extinção.

Breed, M.F., Gardner, M.G., Ottewell, K.M., Navarro, C.M., Lowe, A.J., 2012. Shifts in reproductive assurance strategies and inbreeding costs associated with habitat fragmentation in Central American mahogany. Ecol. Lett. 15, 444-452. https://doi.org/ 10.1111/j.1461-0248.2012.017.

Carneiro, F.S., Degen, B., Kanashiro, M., de Lacerda, A.E.B., Sebbenn, A.M., 2009. High levels of pollen dispersal detected through paternity analysis from a continuous Symphonia globulifera population in the Brazilian Amazon. For. Ecol. Manage. 258, 1260-1266. https://doi.org/10.1016/j.foreco.2009.06.019.

Carneiro, F.S., Lacerda, A.E.B., Lemes, M.R., Gribel, R., Kanashiro, M., Wadt, L.H.O., Sebbenn, A.M., 2011. Effects of selective logging on the mating system and pollen dispersal of Hymenaea courbaril L. (Leguminosae) in the Eastern Brazilian Amazon as revealed by microsatellite analysis. For. Ecol. Manage. 262, 1758-1765. https://doi. org/10.1016/j.foreco.2011.07.023.

Carvalho, A.L., d'Oliveira, M.V.N., Oliveira, L.C., Putz, F.E., 2017. Natural regeneration of trees in selectively logged forest in western Amazonia. For. Ecol. Manage. 392, 36-44. https://doi.org/10.1016/j.foreco.2017.02.049.

CITES, 2019. Conventional on International Trade in Endangered Species of Wild Fauna and Flora, Appendix II. www.cites.org/resources/species.html.

Creste, S., Neto, A.T., Figueira, A., 2001. Detection of single sequence repeat polymorphisms in denaturing polyacrylamide sequencing gels by silver staining. Plant Mol. Biol. Report 19, 299-306. https://doi.org/10.1007/BF02772828.

Dal Bem, E.A., Bittencourt, J.V.M., Moraes, M.L.T., Sebbenn, A.M.S., 2015. Cenários de corte seletivo de árvores na diversidade genética e área basal de populações de Araucaria angustifolia com base em modelagem Ecogene. Sci. For. 43, 453-466.

Davidson, E.A., De Araüjo, A.C., Artaxo, P., Balch, J.K., Brown, I.F., Mercedes, M.M., Coe, M.T., Defries, R.S., Keller, M., Longo, M., Munger, J.W., Schroeder, W., Soares-Filho, B.S., Souza, C.M., Wofsy, S.C., 2012. The Amazon basin in transition. Nature 481, 321-328. https://doi.org/10.1038/nature10717.

Degen, B., Sebbenn, A.M., 2014. Genetics and tropical forests. In: Köhl, M., Pancel, L. (Eds.), Tropical Forestry Handbook. Springer, Berlin, Heidelberg. https://doi.org/10. 1007/978-3-642-41554-8 75-1.

Degen, B., Ward, S.E., Lemes, M.R., Navarro, C., Cavers, S., Sebbenn, A.M., 2013. Verifying the geographic origin of mahogany (Swietenia macrophylla King) with DNAfingerprints. Forensic Sci. Int. Genet. 7, 55-62. https://doi.org/10.1016/j.fsigen. 2012.06.003.

Dering, M., Jerzy, I., Grzegorz, C., 2015. Clonality as a driver of spatial genetic structure in populations of clonal tree species. J. Plant Res. 128, 731-745. https://doi.org/10. 1007/s10265-015-0742-7.

Dick, C.W., Hardy, O.J., Jones, F.A., Petit, R.J., 2008. Spatial scales of pollen and seedmediated gene flow in Tropical Rain Forest trees. Trop. Plant Biol. 1, 20-33. https:// doi.org/10.1007/s12042-007-9006-6.

Dow, B.D., Ashley, M.V., 1996. Microsatellite analysis of seed dispersal and parentage of sampling in bur oak, Quercus macrocarpa. Mol. Ecol. 5, 615-627. https://doi.org/10. 1111/j.1365-294X.1996.tb00357.x.

Doyle, J.J., Doyle, J.L., 1990. Isolation of plant DNA from fresh tissue. Focus 12, 13-15.

Duminil, J., Mendene, A.D.T., Ndiade, B.D., Doucet, J.L., Loo, J., Hardy, O.J., 2016. High selfing rate, limited pollen dispersal and inbreeding depression in the emblematic African rain forest tree Baillonella toxisperma-Management implications. For. Ecol. Manage. 379, 20-29. https://doi.org/10.1016/j.foreco.2016.08.003.

Escribano, P., Viruel, M.A., Hormaza, J.I., 2008. Comparison of different methods to construct a core germplasm collection in woody perennial species with simple sequence repeat markers. A case study in cherimoya (Annona cherimola, Annonaceae), an underutilised subtropical fruit tree species. Ann. Appl. Biol. 153, 25-32. https:// doi.org/10.1111/j.1744-7348.2008.00232.x.

FUNTAC, 1989. Fundação de tecnologia do Estado do Acre. Estrutura do plano de manejo de uso múltiplo da floresta Estadual do Antimary. Rio Branco, Acre.

Ghazoul, J., 2005. Pollen and seed dispersal among dispersed plants. Biol. Rev. 80, 413-443. https://doi.org/10.1017/S1464793105006731.

Gillies, A.C.M., Navarro, C., Lowe, A.J., Newton, A.C., Hernández, M., Wilson, J., Cornelius, J.P., 1999. Genetic diversity in mesoamerican populations of mahogany (Swietenia macrophylla), assessed using RAPDs. Heredity 83, 722-732. https://doi. org /10.1046/j.1365-2540.1999.00626.x.

Giustina, L.D., Baldoni, A.B., Tonini, H., Azevedo, V.C.R., Neves, L.G., Tardin, F.D., Sebbenn, A.M., 2018. Hierarchical outcrossing among and within fruits in Bertholletia excelsa Bonpl. (Lecythidaceae) open-pollinated seeds. Genet. Mol. Res. 17https://doi. org/10.4238/gmr16039872. gmr16039872.

Goudet, J., 1995. Fstat (Version 2.9.3.2): a computer program to calculate $F$-statistics. J. Hered. 86, 485-486. https://doi.org/10.1093/oxfordjournals.jhered.a111627.

Grogan, J., Jennings, S.B., Landis, R.M., Schulze, M., Baima, A.M.V., Lopes, J.C.A., Norghauer, J.M., Oliveira, L.R., Pantoja, F., Pinto, D., Silva, J.N.M., Vidal, E., Zimmerman, B.L., 2008. What loggers leave behind: Impacts on big-leaf mahogany (Swietenia macrophylla) commercial populations and potential for post-logging 
recovery in the Brazilin Amazon. For. Ecol. Manage. 255, 269-281. https://doi.org/ 10.1016/j.foreco.2007.09.048.

Gullison, R.E., Panfil, S.N., Strouse, J.J., Hubbell, S.P., 1996. Ecology and management of mahogany (Swietenia macrophylla King.) in the Chimanes Forest, Beni, Bolivia. Bot. J. Linn. Soc. 122, 9-34. https://doi.org/10.1111/j.1095-8339.1996.tb02060.x.

Hardy, O., Vekemans, X., 2002. SPAGeDI: a versatile computer program to analyze spatial genetic structure at the individual or population levels. Mol. Ecol. Notes 2, 618-620. https://doi.org/10.1046/j.1471-8286.2002.00305.x.

Hedrick, F., 2005. A standardized genetic differentiation measured. Evolution 59, 1633-1638. https://doi.org/10.1111/j.0014-3820.2005.tb01814.x.

Ismail, S.A., Ghazoul, J., Ravikanth, G., Kushalappa, C.G., Shaanker, R.U., Kettle, C.J., 2014. Fragmentation genetics of Vateria indica: implications for management of forest genetic resources of an endemic Dipterocarp. Conserv. Genet. 14, 533-545. https:// doi.org/10.1007/s10592-013-0559-7.

Kalamandeen, M., Gloor, E., Mitchard, E., Quincey, D., Ziv, G., Spracklen, D., Spracklen, B., Adami, M., Aragao, L.E.O.C., Galbraith, D., 2018. Pervasive rise of small-scale deforestation in Amazonia. Sci. Rep. 8, 1-10. https://doi.org/10.1038/s41598-018 19358-2.

Kalinowski, S.T., Taper, M.L., Marshall, T.C., 2007. Revising how the computer program CERVUS accommodates genotyping error increases success in paternity assignment. Mol. Ecol. 16, 1099-1106. https://doi.org/10.1111/j.1365-294X.2007.03089.x.

Lacerda, A.E.B., Kanashiro, M., Sebbenn, A.M., 2008. Effects of Reduced Impact Logging on genetic diversity and spatial genetic structure of a Hymenaea courbaril population in the Brazilian Amazon Forest. For. Ecol. Manage. 255, 1034-1043. https://doi.org/ 10.1016/j.foreco.2007.10.009.

Lacerda, A.E.B., Nimmo, E.R., Sebbenn, A.M., 2013. Modeling the long-term impacts of logging on genetic diversity and demography of Hymenaea courbaril. For. Sci. 59, 15-26. https://doi.org/10.5849/forsci.10-118.

Lemes, M.R., Esashika, T., Gaoue, O.G., 2011. Microsatellites for mahoganies: twelve new loci for Swietenia macrophylla and its high transferability to Khaya senegalensis. Am. J. Bot. 98, 207-209. https://doi.org/10.3732/ajb.1100074.

Lemes, M.R., Gribel, R., Proctor, J., Grattapaglia, D., 2003. Population genetic structure of mahogany (Swietenia macrophylla King, Meliaceae) across the Brazilian Amazon, based on variation at microsatellite loci: Implications for conservation. Mol. Ecol. 12, 2875-2883. https://doi.org/10.1046/j.1365-294X.2003.01950.x.

Lemes, M.R., Grattapaglia, D., Grogan, J., Proctor, J., Gribel, R., 2007. Flexible mating system in a logged population of Swietenia macrophylla King (Meliaceae): implications for the management of a threatened neotropical tree species. Plant Ecol. 192, 169-179. https://doi.org/10.1046/j.1365-294X.2003.01950.x.

Levin, D.A., 1998. The paternity pool plants. Am. Nat. 132, 309-317. https://doi.org/10. $1086 / 284854$.

Loiselle, B.A., Sork, V.L., Nason, J., Graham, C., 1995. Spatial genetic structure of a tropical understory shrub, Psychotria officinalis (Rubiaceae). Am. J. Bot. 82, 1420-1425. https://doi.org/10.1002/j.1537-2197.1995.tb12679.x.

Lourmas, M., Kjellberg, F., Dessard, H., Joly, H.I., Chevallier, M.-H., 2007. Reduced density due to logging and its consequences on mating system and pollen flow in the African mahogany Entandrophragma cylindricum. Heredity 99, 151-160. https://doi. org $/ 10.1038 /$ sj.hdy. 6800976 .

Loveless, M.D., Gullison, R.E., 2003. Genetic variation in natural mahogany populations in Bolivia. Big Leaf Mahogany. Genet. Ecol. Manage. 38, 9-28.

Lowe, A.J., Jourde, B., Breyne, P., Colpaert, N., Navarro, C., Wilson, J., Cavers, S., 2003. Fine-scale genetic structure and gene flow within Costa Rican populations of mahogany (Swietenia macrophylla). Heredity 90, 268-275. https://doi.org/10.1038/sj.hdy 6800247.

Manoel, R.O., Freitas, M.L.M., Júnior, E.F., Alves, P.F., Moraes, M.L.T., Sebbenn, A.M. 2015. Individual, fruit, and annual variation in correlated mating in a Genipa americana population. Silvae Genet. 64, 108-116. https://doi.org/10.1515/sg-2015-0010.

Moghadamtousi, S.Z., Goh, B.H., Chan, C.K., Shabab, T., 2013. Biological activities and phytochemicals of Swietenia macrophylla King. Molecules 18, 10465-10483. https:// doi.org/10.3390/molecules180910465.

Moraes, M.A., Kubota, T.Y.K., Rossini, B.C., Marino, C.L., Freitas, M.L.M., Moraes, M.L.T., Silva, A.M., Cambuim, J., Sebbenn, A.M., 2018. Long-distance pollen and seed dispersal and inbreeding depression in Hymenaea stigonocarpa (Fabaceae: Caesalpinioideae) in the Brazilian savannah. Ecol. Evol. 8, 7800-7816. https://doi. org/10.1002/ece3.4253.

Neto, G., Felfili, J.M., da Silva, G.F., Mazze, L., Fagg, C.W., Ernane, N.P., 2004. Avaliacao do plantion homogeneo de mogno, Swietenia macrophylla King, em comparacao com o plantion consorciado com Eucalyptus urophylla S. T. Blake, apos 40 meses de idade. Rev. Arv. 28, 777-784. https://doi.org/10.1590/S0100-67622004000600002.

Novick, R.R., Dick, C.W., Lemes, M.R., Navarro, C., Caccone, A., Bermingham, E., 2003. Genetic structure of Mesoamerican populations of Big-leaf mahogany (Swietenia macrophylla) inferred from microsatellite analysis. Mol. Ecol. 12, 2885-2893. https:// doi.org/10.1046/j.1365-294X.2003.01951.x.

d'Oliveira, M.V.N., 2000. Artificial regeneration in gaps and skidding trails after mechanized forest exploitation in Acre, Brazil. For. Ecol. Manage. 127, 67-76. https:// doi.org/10.1016/j.foreco.2007.09.051.
Policriti, A., Sgarro, A., 2011. CoreFinder v.1.0. Disponível em: < http:// www Appliedgenomics.org/services/software $>$. Acesso em: 14 mar. 2012

Potascheff, C.M., Oddou-Muratorio, S., Klein, E.K., Figueira, A., Bressan, E.A., Oliveira, P.E., Lander, T.A., Sebbenn, A.M., 2019. Stepping stones or stone dead? Fecundity, pollen dispersal and mating patterns of roadside Qualea grandiflora Mart. trees. Conserv. Genet. https://doi.org/10.1007/s10592-019-01217-w.

Pupin, S., Sebbenn, A.M., Cambuim, J., Silva, A.M., Zaruma, D.U.G., Silva, P.H.M., Rosse, L.N., Souza, I.C., Marino, C.L., Moraes, M.L.T., 2019. Effects of pollen contamination and non-random mating on inbreeding and outbreeding depression in a seedling seed orchard of Eucalyptus urophylla S.T. Blake. For. Ecol. Manage. 437, 272-281. https:// doi.org/10.1016/j.foreco.2019.01.050.

Ritland, K., 1989. Correlated matings in the partial selfer Mimulus guttatus. Evolution 43, 848-859.

Ritland, K., 2002. Extensions of models for the estimation of mating systems using n independent loci. J. Hered. 88, 221-228.

Rosas, F., Quesada, M., Lobo, J.A., Sork, V.L., 2011. Effects of habitat fragmentation on pollen flow and genetic diversity of the endangered tropical tree Swietenia humilis (Meliaceae). Biol. Conserv. 144, 3082-3088. https://doi.org/10.1016/j.biocon.2011. 10.003 .

Sebbenn, A.M., 2006. Sistema de Reprodução em Espécies Tropicais e suas Implicações para a seleção de Árvores Matrizes para Reflorestamentos Ambientais. In: Silva, L.D., Higa, A.R. (Eds.), Pomar de espécies florestais nativas. Curitiba, FUPEF, pp. 93-138.

Sebbenn, A.M., Licona, J.C., Mostacedo, B., Degen, B., 2012. Gene flow in an overexploited population of Swietenia macrophylla King (Meliaceae) in the Bolivian Amazon. Silvae Genet. 61, 212-220. https://doi.org/10.1515/sg-2012-0027.

Sebbenn, A.M., Degen, B., Azevedo, V.C.R., Silva, M., Lacerda, A.E.B., Ciampi, A.Y., Kanashiro, M., Carneiro, F.S., Tompson, I., Loveless, M.D., 2008. Modelling the longterm impact of selective logging on genetic diversity and demographic structure of four tropical tree species in the Amazon forest. For. Ecol. Manage. 254, 335-349. https://doi.org/10.1016/j.foreco.2007.08.009.

SEFA, 2015. Portaria SEFA 704/2015. Fazenda dispõe sobre os preços mínimos de mercado. https://www.contabeis.com.br/legislacao/459325/portaria-sefa-pa-704-2015.

SEMAS, 2015. Secretaria de Estado de meio ambiente e sustentabilidade do Pará Instrução Normativa 08 de 28/10/2015. DOE 33.003 de 03/11/2015. Dispõe sobre procedimentos técnicos para elaboração, apresentação, execução e avaliação técnica de Plano de Manejo Florestal Sustentável - PMFS nas florestas nativas exploradas ou não e suas formas de sucessão no Estado do Pará, e dá outras providências.

Silva, C.R.S., Albuquerque, P.S.B., Ervedosa, F.R., Mota, J.W.S., Figueira, A., Sebbenn, A.M., 2011. Understanding the genetic diversity, spatial genetic structure and mating system at the hierarchical levels of fruits and individuals of a continuous Theobroma cacao population from the Brazilian Amazon. Heredity 106, 973-985. https://doi. org/10.1038/hdy.2010.145.

Silva, M.B., Kanashiro, M., Ciampi, A.Y., Tompson, I., Sebbenn, A.M., 2008. Genetic effects of selective logging and pollen gene flow in a low-density population of the dioecious tropical tree Bagassa guianensis in the Brazilian Amazon. For. Ecol. Manage. 255, 1548-1558. https://doi.org/10.1016/j.foreco.2007.11.012.

SNUC, 2000. Sistema Nacional de Uunidades de Conservação, Lei n. 9.985, de 18 de Julho de 2000 .

Solís-Hernández, W., Fuchs, E.J., 2019. Effective gene flow patterns across a fragmented landscape in southern Costa Rica for Symphonia globulifera (Clusiaceae); a species with mobile seed and pollen dispersers. Rev. Biol. Trop 67 (2), S95-S111.

Styles, B.T., 1972. The flowering biology of the Meliaceae and its baring on tree breeding. Silvae Genet. 21, 172-182.

Tambarussi, E.V., Boshier, D., Vencovsky, R., Freitas, M.L.M., Sebbenn, A.M., 2017. Inbreeding depression from selfing and mating between relatives in the Neotropical tree Cariniana legalis Mart. Kuntze. Conserv. Genet. 18, 225-234. https://doi.org/10 1007/s10592-016-0896-4.

Trujillo-Sierra, J.E., Valerio, P.D., Morillo, I.R., Camacho, V.R., Pérez-Nasser, N., 2013. Variación genética en poblaciones mexicanas de Swietenia macrophylla King, una especie tropical en expansión geográfica reciente. Bot. Sci. 91, 1-11.

Vinson, C., Mangaravite, E., Sebbenn, A.M., Lander, T., 2018. Using molecular markers to investigate genetic diversity, mating system and gene flow of Neotropical trees. Braz. J. Bot. 41, 481-496. https://doi.org/10.1007/s40415-018-0472-x.

Vinson, C.C., Kanashiro, M., Sebbenn, A.M., Williams, T.C.R., Harris, S.A., Boshier, D.H. 2015. Long-term impacts of selective logging on two Amazonian tree species with contrasting ecological and reproductive characteristics: inferences from Eco-gene model simulations. Heredity 115, 130-139. https://doi.org/10.1038/hdy.2013.146.

Wadt, L.H.O., Baldoni, A.B., Silva, V.S., Campos, T., Martins, K., Azevedo, V.C.R., Mata, L.R., Botin, A.A., Hoogerheide, E.S.S., Tonini, H., Sebbenn, A.M., 2015. Mating system variation among populations, individuals and within and among fruits in Bertholletia excelsa. Silvae Genet. 64, 248-259. https://doi.org/10.1515/sg-20150023.

White, G.M., Boshier, D., Powell, W., 2002. Increased pollen flow counteracts fragmentation in tropical dry Forest: an example from Swietenia humilis Zuccarini. Proc. Natl. Acad. Sci. USA 99, 2038-2042. https://doi.org/10.1073/pnas.042649999. 